\title{
Cervical/Vaginal Cytology
}

National Cancer Institute

\section{Source}

National Cancer Institute. Cervical/Vaginal Cytology. NCI Thesaurus. Code C136236.

Cytologic evaluation of cells collected from the uterine cervix and/or vagina. 